\title{
Characterization of Poly (L-co-D,L Lactic Acid) and a Study of Polymer-tissue Interaction in Subcutaneous Implants in Wistar Rats
}

\author{
Giuliano Serafino Ciambelli, Mariana Ortega Perez, Guilherme Vasconcelos Siqueira ${ }^{\mathrm{a}}$, \\ Marco Aurélio Candella , Adriana Cristina Motta a, Marcia Adriana Tomaz Duarte , \\ Maria do Carmo Alberto-Rincon ${ }^{\mathrm{b}}$, Eliana Aparecida de Rezende Duek ${ }^{\mathrm{b}, \mathrm{c} *}$ \\ ${ }^{a}$ Faculty of Medical Sciences, Pontifical Catholic University of São Paulo - PUC-SP, \\ CEP 18030-095, Sorocaba, SP, Brazil \\ ${ }^{\mathrm{b}}$ Department of Physiological Sciences, Faculty of Medical Sciences, \\ Pontifical Catholic University of São Paulo - PUC-SP, \\ CEP 18030-095, Sorocaba, SP, Brazil \\ ${ }^{\mathrm{c}}$ Department of Materials Engineering, Faculty of Mechanical Engineering, \\ State University of Campinas - UNICAMP, \\ CEP 13083-970, Campinas, SP, Brazil
}

Received: March 23, 2012; Revised: June 26, 2012

\begin{abstract}
Poly (L-co-D,L lactic acid) (PLDLA) is an important biomaterial because of its biocompatibility properties that promote cellular regeneration and growth. The aim of this study was to evaluate the polymer-tissue interaction of PLDLA implants in the dorsal subcutaneous tissue of male Wistar rats at various intervals $(2,7,15,30,60$ and 90 days) after implantation. Physical properties such as the glass transition point $(\mathrm{Tg})$, degradation behavior and other mechanical properties were characterized by differential scanning calorimetry (DSC), thermogravimetric analysis (TGA), gel permeation chromatography (GPC), scanning electron microscopy (SEM) and tension tests. Analysis of the degradation of PLDLA membranes in vitro showed that the polymer became crystalline as a function of the degradation time. Mechanical tension tests showed that the polymer behaved like a ductile material: when subjected to constant tension it initially suffered deformation, then elongation and finally ruptured. TGA/MEV provided evidence of PLDLA membrane degradation. For histological analysis, samples from each group were processed in xylol/paraffin, except for the 60 - and 90 - day samples. Each of the latter samples was divided in two: one half was treated with xylol/paraffin and the other with historesin. Light microscopy showed the adhesion of cells to the biomaterial, the formation of a conjunctive capsule around the implant, the presence of epithelioid cells, the formation of foreign body giant cells and angiogenesis. During degradation, the polymer showed a 'lace' - like appearance when processed in xylol/paraffin compared to the formation of "centripetal cracks in the form of glove fingers" when embedded in historesin.
\end{abstract}

Keywords: PLDLA, degradation in vitro, tissue

\section{Introduction}

Polymers are the components of choice for therapeutic implants because of their ability to mimic the appearance of the original injured tissue and promote tissue reconstitution. For this reason, polymers need to be biocompatible and bioresorbable in order to minimize adverse reactions to the organism ${ }^{1,2}$. The increasing therapeutic use of polymers as biomaterial implants makes it essential to evaluate the behavior of subcutaneous implants in vivo. This is generally done in rats, which provide an ideal model for analyzing the rate of neovascularization, the formation of collagen types I and III, and consolidation of the conjunctive capsule around the polymer ${ }^{3}$.

*e-mail: eliduek@fem.unicamp.br
Among biomaterials, poly-L/DL-lactide (PLDLA), an amorphous and bioresorbable material, has a structure that combines the best characteristics of poly (L-lactic acid) and poly (D-lactic acid), i.e., the mechanical properties of the first and the shorter degradation time of the second; these properties have made PLDLA a compound of great relevance in the controlled release of drugs and the treatment of bone fractures ${ }^{4,5}$. In addition to these applications, PLDLA has been used to treat skin ulcers and as a support for culturing chondrocytes in vitro ${ }^{4}$.

The aim of this work was to evaluate the polymer-tissue interaction at various intervals after the dorsal subcutaneous implantation of PLDLA membranes in male Wistar rats. The degradation of these membranes in vitro was also assessed. 


\section{Material and Methods}

\subsection{Membrane preparation}

Poly (L-co-D,L lactic acid) (PLDLA; 70:30; $\mathrm{Mw}=282700 \mathrm{~g} \cdot \mathrm{mol}^{-1}$ ) was synthesized via bulk ring-opening copolymerization of L-lactide and D,L lactide, using stannous octoate as the catalyst, essentially as described by Motta ${ }^{6}$. PLDLA membranes were prepared by the solvent casting technique. Polymeric solutions containing copolymer at a concentration of $2.5 \% \mathrm{~m} / \mathrm{v}$ were prepared by dissolving PLDLA in dichloromethane (Merck KgaA, Darmstadt, Germany). After complete dissolution of the copolymer with mixing for $2 \mathrm{~h}$, the solution was poured into a glass mold, with care being taken to avoid the formation of bubbles. The mold containing the solution was placed in a glass vat saturated with solvent vapor for $24 \mathrm{~h}$; the solvent was carried along by a flow of dry air that allowed the formation of membranes. After solvent evaporation, the membranes were dried under vacuum for $8 \mathrm{~h}$ and stored in a desiccator under vacuum until they were characterized.

\subsection{Physicochemical characterization of PLDLA membranes}

\subsubsection{Degradation in vitro}

PLDLA membranes were immersed in tubes containing phosphate buffer ( $\mathrm{pH}$ 7.4) in a thermally controlled bath at $37 \pm 0.5^{\circ} \mathrm{C}$ and left for $4,8,12$ and 24 weeks.

\subsubsection{Differential scanning calorimetry (DSC)}

Calorimetric measurements were done with a DSC 2920 calorimeter (TA-Instruments) in which 7-10 mg samples sealed in aluminum pans were heated from $25^{\circ} \mathrm{C}$ to $200{ }^{\circ} \mathrm{C}$ at a rate of $10^{\circ} \mathrm{C} / \mathrm{min}$ and maintained at the final temperature for 5 minutes prior to cooling to $25^{\circ} \mathrm{C}$ at the same rate. The samples were maintained at $25{ }^{\circ} \mathrm{C}$ for 5 minutes and then re-heated. All tests were done under a nitrogen atmosphere.

\subsubsection{Tension tests}

Tension tests were done at room temperature using an MTS (TestStar II) according to ASTM D790-95a. Young's modulus was determined by the angular coefficient of the linear curve of tension vs. deformation. The results shown are the average of measurements on five samples.

\subsubsection{Scanning electron microscopy (SEM)}

Samples of PLDLA membrane were freeze-fractured in liquid nitrogen and sputter-coated with gold (layer thickness: $25 \mathrm{~nm}$ ) using a Balzers SCD 050 sputterer. The samples were examined with a Jeol JMS 5800 LV scanning electron microscopy (Japan) operated at 10-20 kV.

\subsubsection{Thermogravimetric analysis (TGA)}

TGA was done in a STA 409C analyzer (NETZSCH - Gerätebau GmbH Thermal Analysis). The samples were heated from room temperature to $450{ }^{\circ} \mathrm{C}$ at a heating rate of $10^{\circ} \mathrm{C} / \mathrm{min}$ under a helium atmosphere.

\subsubsection{Gel permeation chromatography (GPC)}

The average molar mass in weight $\left(\mathrm{M}_{\mathrm{w}}\right)$ and number $\left(\mathrm{M}_{\mathrm{n}}\right)$ and the polydispersivity before and after degradation in vitro were determined by gel permeation chromatography (GPC) using a column of Ultrastyragel (Waters) coupled to a refraction index detector. Samples of $200 \mu \mathrm{L}$ were dissolved in $10 \mathrm{~mL}$ of tetrahydrofuran (Merck) and applied to the column, which was eluted with tetrahydrofuran at a rate of $1 \mathrm{~mL} / \mathrm{min}$. The molar mass and rate of polydispersivity were calculated using polystyrene as a standard.

\subsection{Analysis of PLDLA membranes in vivo}

Male Wistar rats (3 months old; 300 g), obtained from the Center of Medical Sciences and Biology of the Pontifical Catholic University of São Paulo (PUC/SP, Sorocaba, SP), were housed at $22 \pm 2{ }^{\circ} \mathrm{C}$ on a $12 \mathrm{~h}$ light/dark cycle and received food and water ad libitum. All procedures involving animals were approved by the Ethics Committee of the Universidade do Vale do Paraíba (UNIVAP), São José dos Campos, SP, Brazil (protocol no. A062/CEP/209).

For use in vivo, PLDLA membranes were immersed in $70 \%$ ethanol and dried under vacuum, after which a fragment of membrane was implanted subcutaneously in the dorsum of each rat. For this, rats were anesthetized (ketamine $100 \mathrm{mg} \cdot \mathrm{kg}^{-1}$; xylazine $6 \mathrm{mg} \cdot \mathrm{kg}^{-1}$, i.m.), placed in ventral decubitus and the hair close to the cervical area was clipped. Subsequently, a membrane disc $6 \mathrm{~mm}$ in diameter was implanted subcutaneously through a medial incision about $1 \mathrm{~cm}$ long. After implantation, the incision was sutured with 5-0 nylon thread and iodine alcohol was used as aseptic solution.

The health and behavior of the rats were assessed daily. At predetermined intervals after membrane implantation, the rats were anesthetized with ether and killed by cervical dislocation. Subsequently, using the scar formed at the site where the membranes were implanted and the membrane impression on the skin as a guide, the dorsal hair was clipped again and tissue fragments were removed from the area surrounding the implant. The fragments were fixed in $4 \%$ paraformaldehyde and processed for histological analysis.

\subsection{Histological analysis}

Tissue fragments were fixed in $4 \%$ paraformaldehyde at $4{ }^{\circ} \mathrm{C}$ for $24 \mathrm{~h}$. After fixation, the samples were washed in distilled water, dehydrated in an increasing series of ethanol, cleared in xylol and soaked in paraffin (Histosec, Merck). Sections $4 \mu \mathrm{m}$ thick were cut with a Leica RM 2245 microtome using disposable blades and immediately stained with hematoxylin-eosin (HE).

Half of the samples collected 60 and 90 days after implantation were processed as described above and the other half was processed for inclusion in historesin. For the latter procedure, the samples were initially fixed in $4 \%$ paraformaldehyde in $0.1 \mathrm{M}$ phosphate buffer ( $\mathrm{pH} 7.4$ ) for $24 \mathrm{~h}$. After fixation, the samples were rinsed in $0.1 \mathrm{M}$ phosphate buffer ( $\mathrm{pH} 7.4$ ), dehydrated in an increasing ethanol series, soaked in $100 \%$ ethanol and resin $(1: 1)$ for $2 \mathrm{~h}$ and then embedded in resin for subsequent polymerization. Section $3 \mu \mathrm{m}$ thick were cut on a Leica RM 245 microtome with glass blades and stained with $0.25 \%$ toluidine blue solution in $5 \%$ Borax.

The stained sections were examined with a Nikon Eclipse E800 microscope and images were captured and analyzed with the software Image Pro Lite. 


\section{Results and Discussion}

\subsection{Mechanical and physicochemical properties}

The crystallization of copolymers has received considerable attention in recent years because of the mechanical performance and enhanced biodegradation of these compounds ${ }^{7}$. The glass transition temperature $(\mathrm{Tg})$ is a useful parameter for assessing the amorphous phase while the melting temperature $(\mathrm{Tm})$ provides information on the crystalline phase of these mixtures.

The thermal behavior of PLDLA membranes was examined by DSC. Figure 1 shows the behavior for the second heating of PLDLA membranes after 0, 4, 8, 12 and 24 weeks of hydrolytic degradation. During storage for up to 12 weeks before degradation the $\mathrm{Tg}$ was $56^{\circ} \mathrm{C}$; this reflected the random distribution of the levo $(\mathrm{L})$ and dextro (D) rotatory units of the polymeric chain that prevented crystallization and created an amorphous phase. The Tg decreased during the first 12 weeks of degradation but increased after 24 weeks. Crystallization and a melting peak were observed after 24 weeks of degradation.

Table 1 summarizes the data obtained from the DSC curves. There was no change in the $\mathrm{Tg}$ during the first four weeks of degradation whereas from the $8^{\text {th }}$ to the $12^{\text {th }}$ week the Tg decreased from $42{ }^{\circ} \mathrm{C}$ to $22{ }^{\circ} \mathrm{C}$ when compared with membrane not exposed to degradation. After 24 weeks of degradation, crystallization and melting peaks occurred at $80{ }^{\circ} \mathrm{C}$ and $108{ }^{\circ} \mathrm{C}$, respectively, and were related to the crystalline phase that appeared during degradation.

Poly (hydroxy acid) degradation in vitro is generally considered to be heterogeneous and is more rapid in the center than at the surface when the devices are in contact with an aqueous medium ${ }^{8}$. Initially, degradation probably occurs mainly on the surface because of the absorption gradient of water, but as the concentration of carbonyl groups increases in the center these serve as catalysts for degradation. This self-catalyzing behavior is common during the degradation of aliphatic polyesters. However, the process depends on the chemical structure and configuration of the polymeric chains, as well as the morphology of the device involved. Middeleton et al. ${ }^{9}$ confirmed such self-catalysis when they showed that non-porous membranes undergo degradation more rapidly than porous ones because the latter facilitate the dissolution and dispersion of the degradation products throughout the aqueous medium, thereby limiting self-catalysis.

Since the $\mathrm{Tg}$ is related to the temperature at which the chains acquire motion a decrease in this parameter during degradation can be explained by the formation of shorter chains, which require a lower temperature to promote motion. In agreement with this, Baraúna et al. ${ }^{10}$, in an in vitro study of PLDLA membranes obtained by casting, observed a decrease in the $\mathrm{Tg}$ as a function of the degradation time and this effect was more evident after 18 weeks of degradation. Motta et al. ${ }^{11}$ observed a decrease in the Tg of PLGA with crystal formation after 15 days of degradation.

In contrast to the decrease seen at 12 weeks, there was an increase in the $\mathrm{Tg}$ from the $12^{\text {th }}$ to the $24^{\text {th }}$ week of degradation (from $22{ }^{\circ} \mathrm{C}$ to $29^{\circ} \mathrm{C}$ ) and very defined peaks of crystallization and melting (Table 1). This increase can be explained by the difficulty of chains movement because

Table 1. Glass transition (Tg), melting temperature (Tm), melting enthalpy $(\Delta \mathrm{Hm})$, crystallization temperature $(\mathrm{Tc})$ and crystallization enthalpy $(\Delta \mathrm{Hc})$ determined by DSC for PLDLA membranes in relation to the length of degradation (weeks).

\begin{tabular}{cccccc}
\hline $\begin{array}{c}\text { Time } \\
\text { (weeks) }\end{array}$ & $\mathbf{T}_{\mathbf{g}}\left({ }^{\circ} \mathbf{C}\right)$ & $\mathbf{T}_{\mathbf{m}}\left({ }^{\circ} \mathbf{C}\right)$ & $\begin{array}{c}\Delta \mathbf{H m} \\
\left(\mathbf{k J} / \mathbf{m o l}^{-1}\right)\end{array}$ & $\mathbf{T}_{\mathbf{c}}\left({ }^{\circ} \mathbf{C}\right)$ & $\begin{array}{c}\Delta \mathbf{H c} \\
\left(\mathbf{k J} / \mathbf{m o l}^{-1}\right)\end{array}$ \\
\hline 0 & 54 & - & - & - & - \\
4 & 54 & - & - & - & - \\
8 & 42 & - & - & - & - \\
12 & 22 & 104 & 0.02 & - & - \\
24 & 29 & 108 & 30 & 81 & 27.64 \\
\hline
\end{tabular}

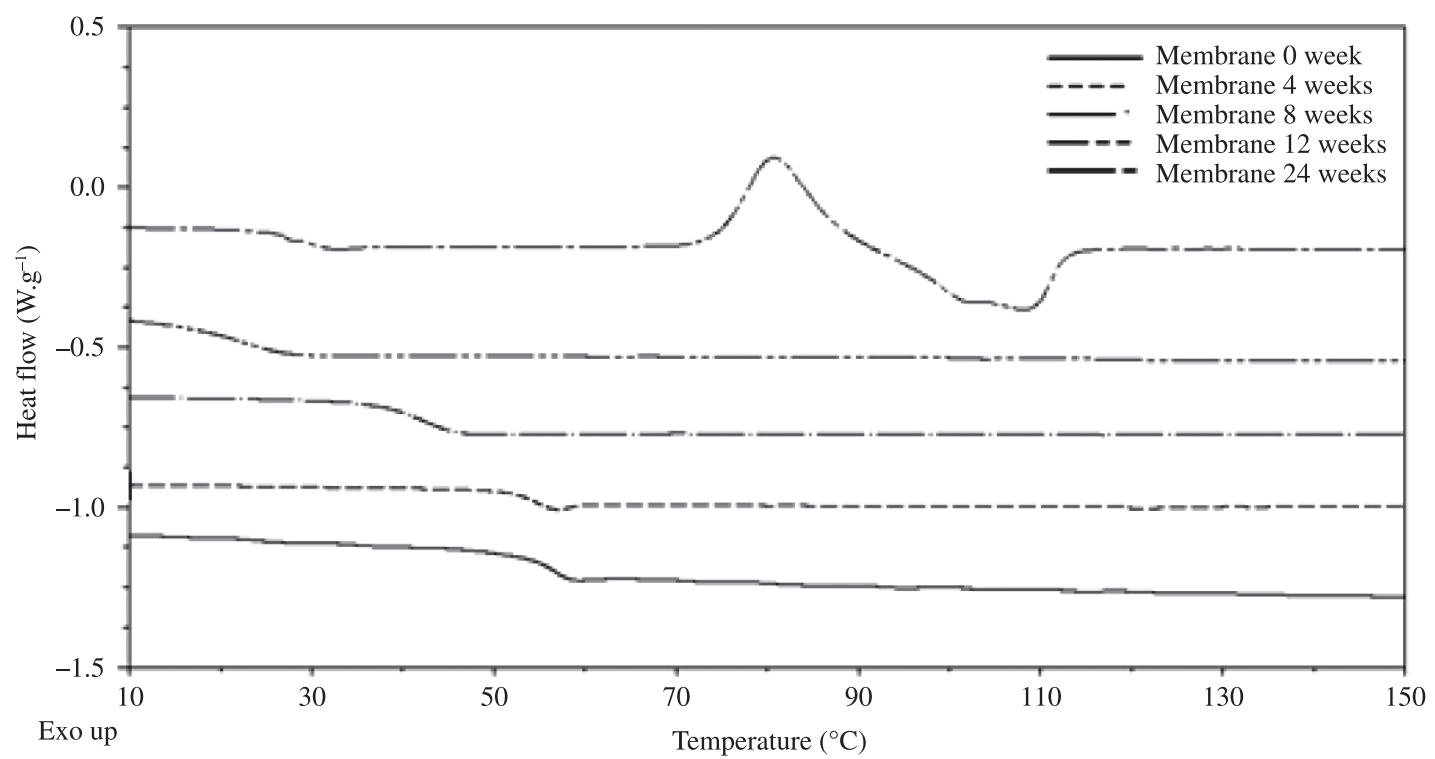

Figure 1. DSC curves for PLDLA membranes submitted to different hydrolytic degradation periods, 0, 4, 8, 12, 24 weeks, second heating. 
of the increased crystallinity of the material that probably occurred during degradation. Li et al. ${ }^{12}$ examined the crystallization of PLGA during degradation and suggested that this phenomenon occurred preferentially in amorphous glycolic units and residual lactic units that became isostatic and, consequently, more crystalline. A similar conclusion was reached by Motta et al. ${ }^{11}$ in a study of PLDLA copolymer

The mechanical tension test showed that PLDLA behaved like ductile material, i.e., when subjected to constant tension it initially suffered deformation, then elongation and finally ruptured. Table 2 shows the variation in Young's modulus, the elongation at break and the maximal tension as a function of the degradation time. Initially the mechanical behavior of the PLDLA copolymer was typical of a vitreous polymer, with a Young's modulus of $1564 \pm 141 \mathrm{MPa}$, a tension stress of $21.0 \pm 5.5 \mathrm{MPa}$ and an elongation at break of $8.7 \pm 1.2 \%$. After four weeks, there was a $61 \%$ decrease in the modulus of elasticity and elongation values. After this interval, it was not possible do the tests because the material became very fragile.

One factor that affects the mechanical properties of copolymers is the decrease in molar mass that results from hydrolytic degradation. As shown here, the membranes lost their mechanical properties after four weeks. Whatever the application, it is very important that the material maintain its mechanical properties until it has completed its function. As shown elsewhere ${ }^{13,14}$, poly (L-lactic acid) pins that had an elasticity modulus of 3-5 GPa before degradation became fragile after two weeks in phosphate buffer. In this case, since the crystallinity of the polymer increased as a function of the degradation time since its fragments remained in the organism, but the device did not retain its mechanical properties.

The mechanical properties of polymeric compounds reported in the literature are difficult to compare because of the different methods used in analysis, the characteristics of the materials and the process to which the polymer was submitted.

Table 2. Maximum stress, elongation at fracture and modulus of elasticity for PLDLA membranes during hydrolytic degradation in vitro for 24 weeks.

\begin{tabular}{cccc}
\hline $\begin{array}{c}\text { Degradation } \\
\text { time (weeks) }\end{array}$ & $\begin{array}{c}\text { Maximum } \\
\text { stress } \\
\left(\sigma_{\text {máx }}\right)(\mathbf{M P a})\end{array}$ & $\begin{array}{c}\text { Elongation at } \\
\text { fracture }(\varepsilon) \\
(\%)\end{array}$ & $\begin{array}{c}\text { Modulus of } \\
\text { elasticity (E) } \\
(\mathbf{M P a})\end{array}$ \\
\hline 0 & $21.15 \pm 5.51$ & $8.70 \pm 1.22$ & $1564 \pm 141$ \\
4 & $18.60 \pm 0.60$ & $4.10 \pm 1.20$ & $605 \pm 23$ \\
\hline
\end{tabular}

The results are expressed as the mean \pm SEM. Extensive degradation of the material after 12 weeks and 24 weeks precluded tensile tests.

Table 3. Initial temperature of mass loss $\left(\mathrm{T}_{\text {onset }}\right)$ and temperature of maximum mass loss $\left(\mathrm{T}_{\text {peak }}\right)$ for PLDLA determined by TGA during hydrolytic degradation in vitro for 24 weeks.

\begin{tabular}{ccc}
\hline Degradation time (weeks) & $\mathbf{T}_{\text {onset }}\left({ }^{\circ} \mathbf{C}\right)$ & $\mathbf{T}_{\text {peak }}\left({ }^{\circ} \mathbf{C}\right)$ \\
\hline 0 & 340 & 354 \\
4 & 325 & 354 \\
12 & 285 & 342 \\
24 & 278 & 333 \\
\hline
\end{tabular}

PLDLA membranes were analyzed by TGA and the results as a function of degradation time are shown in Table 3. A decrease in the initial temperature of mass loss $\left(\mathrm{T}_{\text {onset }}\right)$ and in the temperature of maximum mass loss $\left(\mathrm{T}_{\text {peak }}\right)$ indicated that the polymer had undergone degradation. This degradation was greater from the $4^{\text {th }}$ to $12^{\text {th }}$ week $(12 \%$ degradation) compared to the first four weeks and after the $24^{\text {th }}$ week (4\% and $2.4 \%$ degradation, respectively). The decrease in degradation rate from the $24^{\text {th }}$ week onwards can be attributed to backbone accumulation during degradation that prevented crystallization of the material and made hydrolysis difficult. This increase in crystallinity was confirmed by DSC.

Figure 2 shows electron micrographs of the upper surfaces of PLDLA membranes exposed to degradation for 0,4 and 12 weeks. Before degradation, the membranes had a dense morphology without pores (Figure 2a) whereas a discrete increase in porosity was observed after 4 and 12 weeks (Figure 2b, c, respectively). The fracture surface of the membranes also showed signs of degradation (Figure 3 ). During the first four weeks of degradation the material retained its dense morphology (Figure 3a, b). After 12 weeks, pores and cracks were observed in the center of the sample (Figure 3c), which suggested heterogeneous degradation, as indicated by DSC. After 24 weeks there was radially oriented degradation (Figure 3d, e) that was attributed to an increase in crystallinity. Pezzin ${ }^{15}$ also observed radially oriented structures (spherulites) in PLLA/PDS pins prepared by melting and subjected to 15 weeks of degradation.

Table 4 shows the variation in the average molar mass of PLDLA membranes as a function of the degradation time. This analysis confirmed degradation of the polymer as a function of the length of immersion in phosphate buffer. GPC analysis yielded data on the average molar mass weight $(\mathrm{Mw})$, the average molar mass number $(\mathrm{Mn})$ and the polydispersion index (PI). The values for Mw and Mn decreased as a function of hydrolysis.

\subsection{Biomaterial-tissue interaction}

\subsubsection{Macroscopic analysis}

The implants had no effect on the health and behavior of the rats. There was no significant adherence between tissue and polymer for implants on days 2 and 7 . In contrast, 15-day implants showed greater polymer-tissue attachment. This finding suggests that the polymer-tissue process tended to increase gradually through organization of the conjunctive tissue fibers into a conjunctive capsule, as discussed below for the microscopic analysis.

Table 4. Average molar mass weight (Mw), average molar mass number (Mn) and polydispersion index (PI) of PLDLA determined by GPC during hydrolytic degradation in vitro for 24 weeks.

\begin{tabular}{cccc}
\hline $\begin{array}{c}\text { Degradation } \\
\text { time (weeks) }\end{array}$ & $\begin{array}{c}\text { Mw (Dalton) } \\
\times \mathbf{1 0}^{\mathbf{3}}\end{array}$ & $\begin{array}{c}\text { Mn (Dalton) } \\
\times \mathbf{1 0}^{\mathbf{3}}\end{array}$ & PI \\
\hline 0 & 265 & 137 & 1.9 \\
4 & 47 & 20 & 2.2 \\
8 & 5.8 & 2.3 & 2.5 \\
12 & 3.7 & 1.4 & 1.5 \\
24 & 1.9 & 1.4 & 1.3 \\
\hline
\end{tabular}


The implants removed on days 15 and 30 showed no marked reduction in polymer size, although there was important polymer-tissue attachment. On the other hand, there was a significant reduction in polymer size in the 60 - and 90 - day samples; this reduction corresponded to approximately half of the initial size ( $6 \mathrm{~mm}$ in diameter) for the 60 - day implants and slightly less than three-quarter of the initial size in the 90 - day samples. Examination of the latter samples showed that the polymer surface and its adjacent tissue were rigid to touch and the polymer membrane was brittle and broken. There was a consolidated attachment between the polymer and surrounding tissue in the 60 - and 90 - day samples. There was no inflammatory response (edema or redness).

\subsubsection{Microscopic analysis}

The histological alterations associated with each implantation interval $(2,7,15,30,60$ and 90 days) as assessed by light microscopy are described below.

\subsubsection{Second day of implantation}

Sections from two-day implants revealed the presence of cells adhered to the polymer surface; there was also a poorly defined conjunctive capsule and a fibrin net around the polymer (Figure 4).

\subsubsection{Seventh day of implantation}

In seven-day implants the formation of collagen fibers was more organized and produced a better defined capsule around the polymer (Figure 5), when compared with the two-day implants.

\subsubsection{Fifteenth day of implantation}

Fifteen-day implants showed polymer degradation that formed a lace-like structure and the presence of foreign body giant cells and macrophage-like epithelioid cells at the edge of the conjunctive capsule. Angiogenesis was also observed in areas intimately associated with the conjunctive capsule (Figures 6 and 7).

\subsubsection{Thirtieth day of implantation}

Thirty days after implantation, the consolidated conjunctive capsule was easily seen and showed cellular invasion of the area occupied by the polymer that suggested rupture of the polymeric membrane. Foreign body giant cells were present and angiogenesis was easily detected (Figure 8).

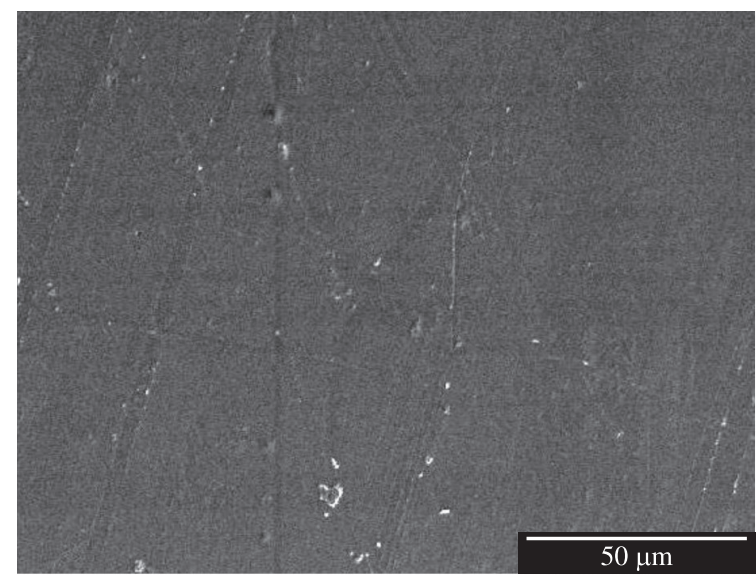

(a)

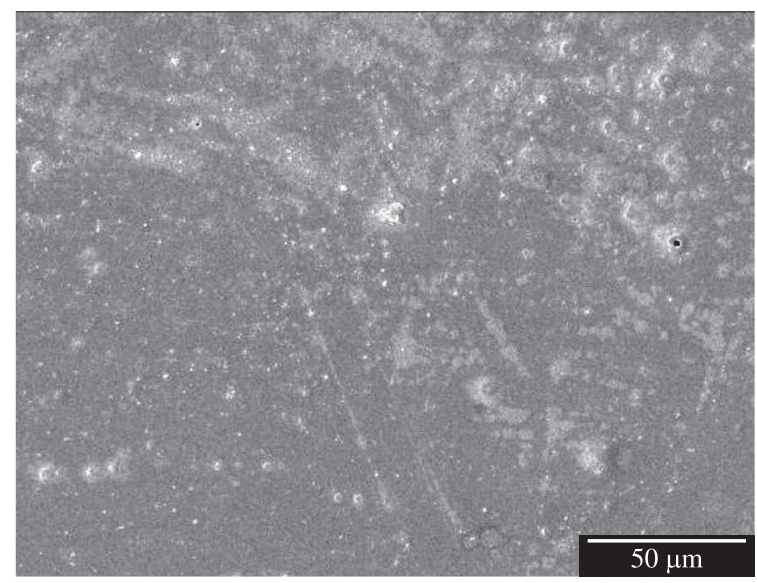

(b)

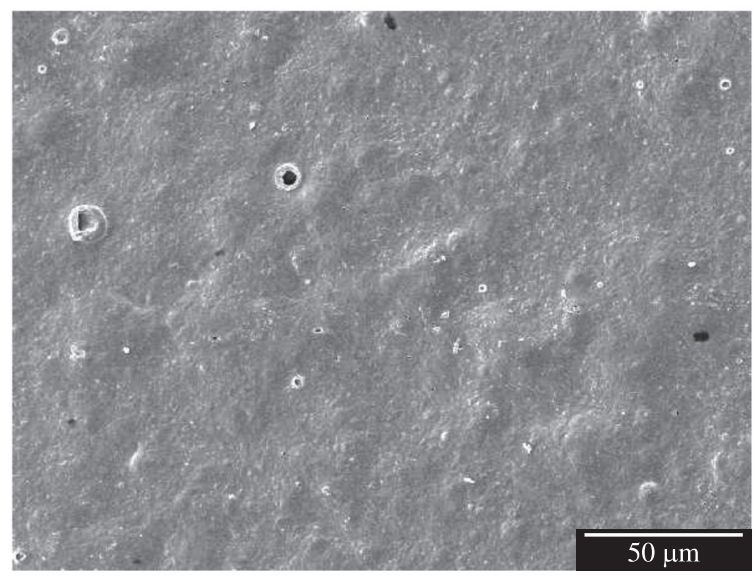

(c)

Figure 2. Electron Micrographs of surfaces of PLDLA membranes submitted to different degradation periods a) $t=0$ weeks; $b$ ) $t=4$ weeks and c) 12 weeks. 


\subsubsection{Sixtieth day of implantation}

- Samples embedded in paraffin

Polymer fragmentation and cellular invasion were observed in 60-day samples. There was also a conjunctive capsule with an epithelioid arrangement of macrophage-like cells at the edge. Foreign body giant cells were also seen, as was extensive angiogenesis (Figure 9).

- Samples embedded in historesin

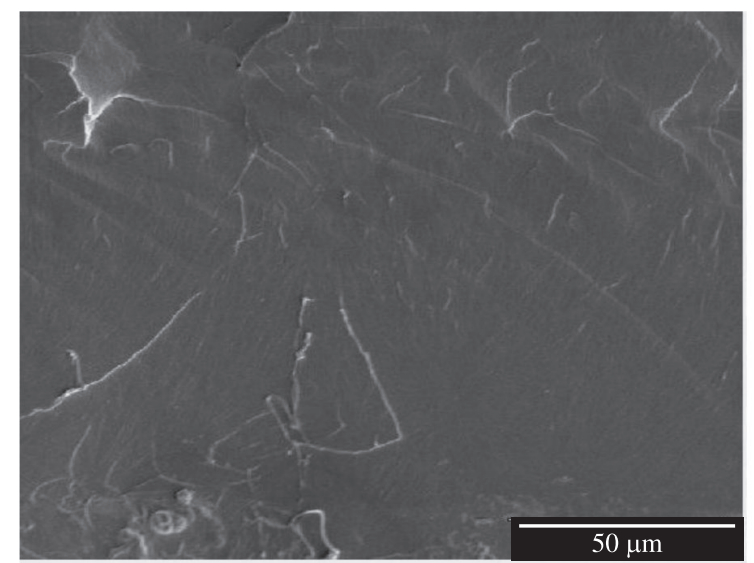

(a)

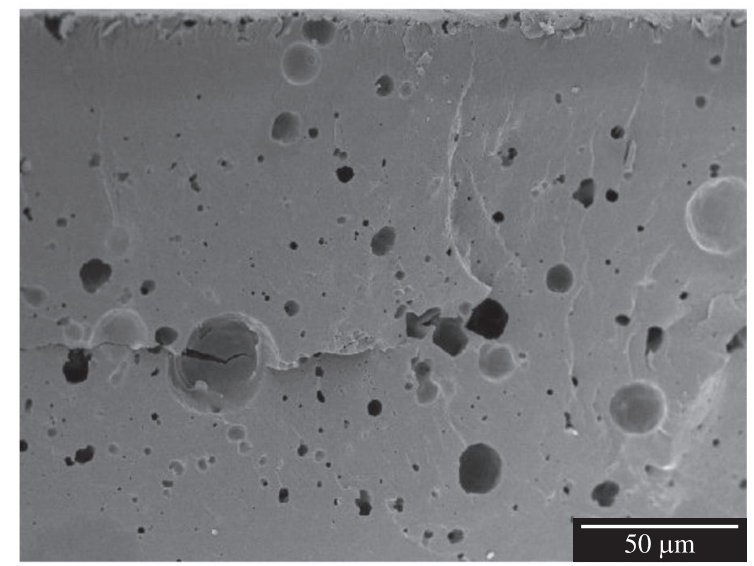

(c)
Polymer fragmentation, a definitely consolidated conjunctive capsule and foreign body giant cells were observed in the 60-day implants (Figure 10).

\subsubsection{Ninetieth day of implantation}

- Samples embedded in paraffin

Light microscopy showed that in 90-day implants foreign body giant cells were molded to the polymer and the

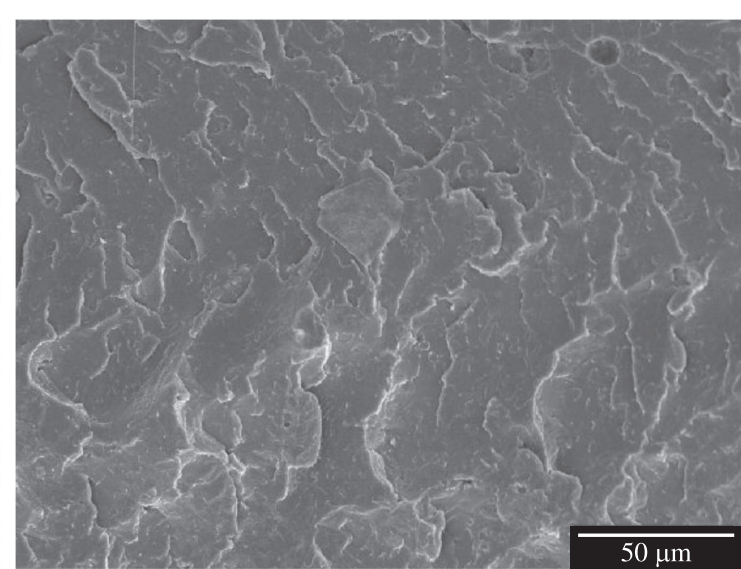

(b)

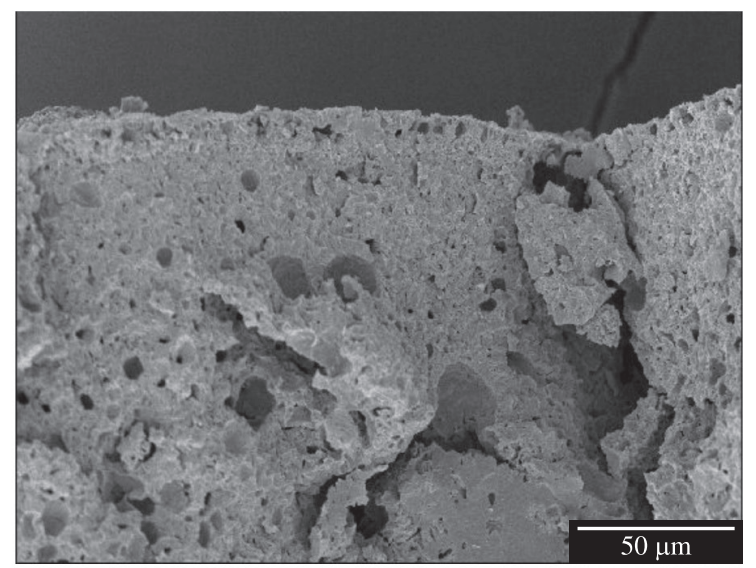

(d)

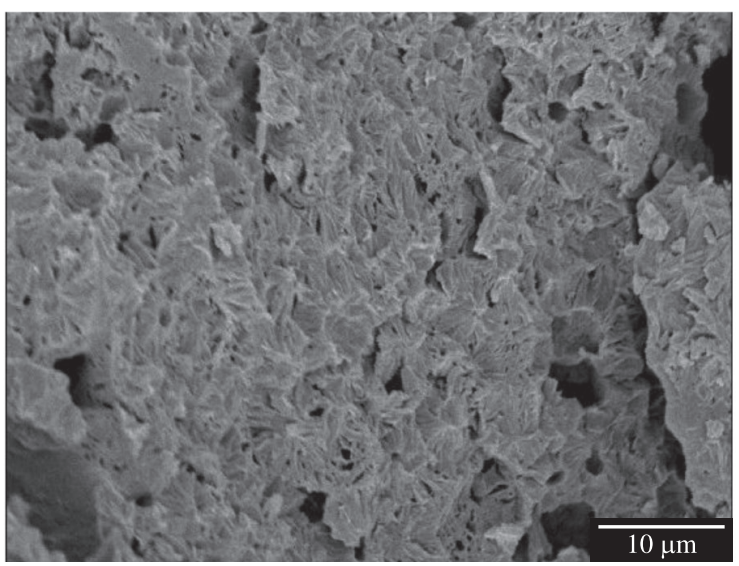

(e)

Figure 3. Electron Micrographs of fracture surfaces of PLDLA membranes submitted to different degradation periods a) $t=0$ weeks; b) $\mathrm{t}=4$ weeks c) 12 weeks; d) 24 weeks $500 \times$ e) 24 weeks $2000 \times$. 


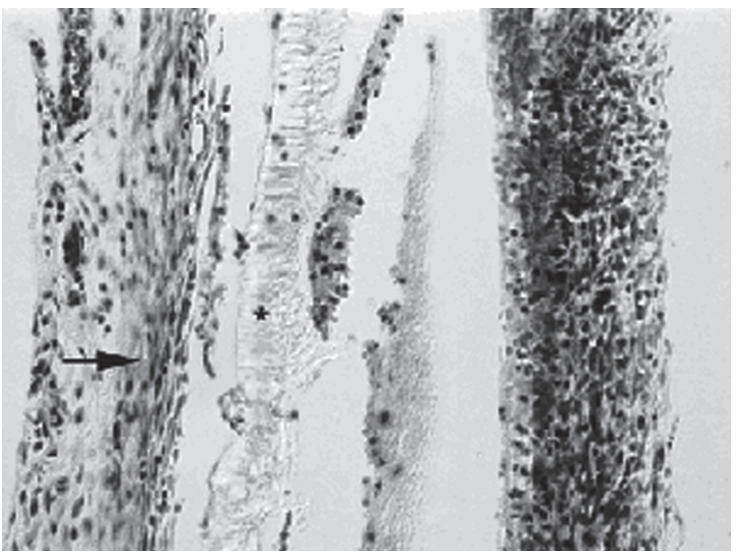

Figure 4. Photomicrography of PLDLA membrane two days after implantation. Observe the beginning of the collagen fiber organization (arrow) around the polymer $(*)$, showing the beginning of capsule formation. H.E. 400x.

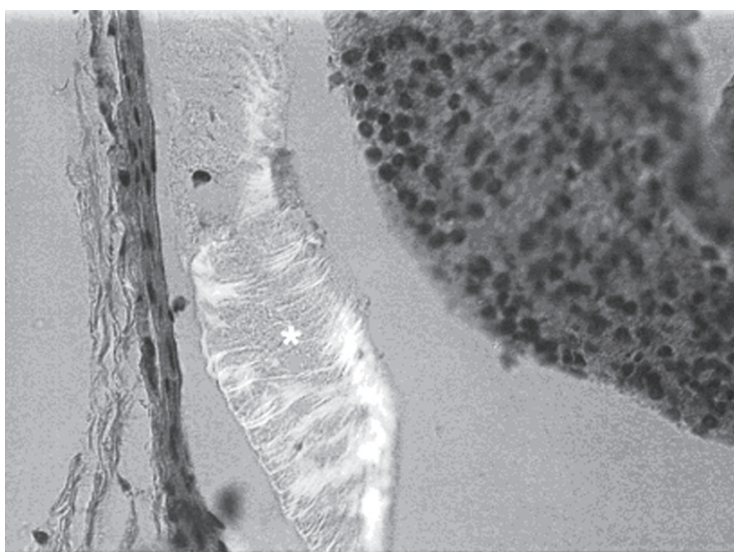

Figure 5. Polarized light photomicrography, in evidence PLDLA membrane $\left(^{*}\right)$ seven days after implantation. H.E. 400×.

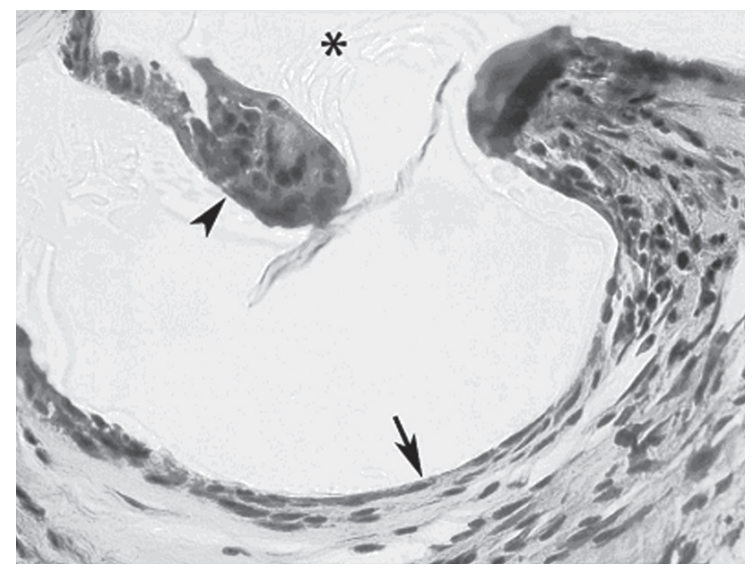

Figure 6. Photomicrography of PLDLA membrane fifteen days after implantation. Attempt to form the conjunctive capsule (arrow) around the polymer $(*)$ and the presence of foreign body giant cell (arrow head). H.E. 400x. conjunctive capsule contained macrophage-like epithelioid cells; angiogenesis was also observed (Figure 11).

- Samples embedded in historesin

Sections of historesin-embedded implants showed the polymer, its fragmentation and foreign body giant cells (Figure 12).

Absorbable polymers that undergo biodegradation and bioresorption, such as PLDLA, act as a substrate for cell growth. As soon as the cells grow and unite to form tissues, the PLDLA membranes are degraded and absorbed by the organism ${ }^{16,17}$. As the biomaterial fragments are being eliminated, inflammatory reactions may develop in response to phagocytosis by macrophages ${ }^{4,18}$.

In this work, we examined the relationship between PLDLA membrane implantation and tissue response in vivo. The latter includes: (1) cellular adhesion, (2) cellular proliferation and (3) organization of a conjunctive capsule the function of which is to isolate the foreign body (polymeric membrane). In addition to these processes, neoangiogenesis is an indispensable mechanism for cellular proliferation and migration of the mononuclear phagocytic system.

In this study, cellular adhesion was observed two days after implantation. Cellular adhesion is correlated with the chemical composition and topography of the polymeric membrane, which directly affects the adsorption of molecules derived from the extracellular matrix and cell-substratum relationship ${ }^{19}$. Polymeric surface factors that can modify the cellular adhesion include aspects such as superficial micromorphology, hydrophilicity, surface electric charges, free energy and chemical groups. These characteristics can stimulate a wide range of cellular functions capable of modifying cell signaling and proliferation that affect cell differentiation, growth, tissue morphology and extracellular matrix production ${ }^{19}$.

Two-day implants showed a poorly consolidated conjunctive capsule that became well-defined by the seventh day after implantation. At this time, the conjunctive capsule was organized around the polymer to promote isolation of the foreign body.

Cicatrization involves the construction of a provisory matrix of type III collagen through the action of platelet-derived growth factor (PDGF) that sensitizes fibroblasts $^{3,20}$. Type III collagen fibers contribute to the

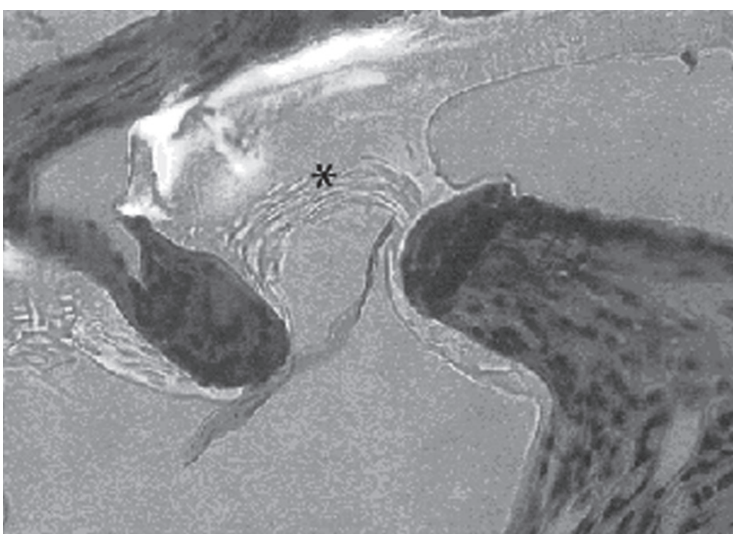

Figure 7. Polarized light photomicrography, in evidence PLDLA membrane (*) fifteen days after implantation. H.E. 400x. 


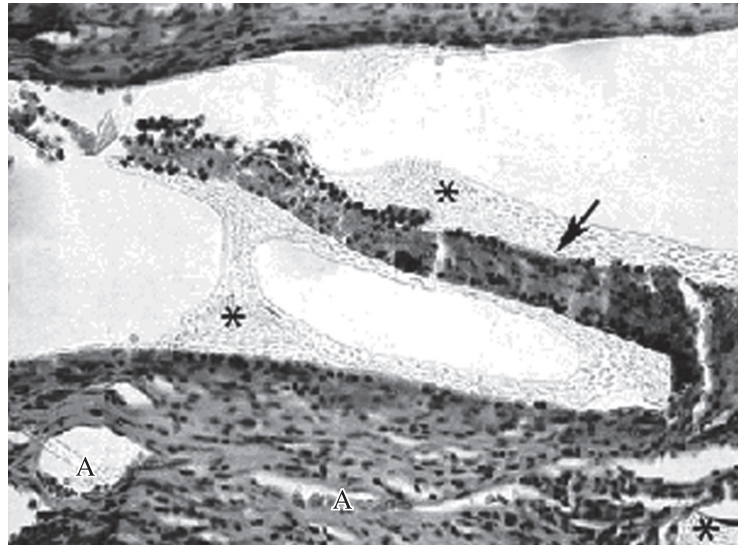

Figure 8. Photomicrography of PLDLA membrane thirty days after implantation. Notice cellular invasion (arrow) inside the area of the polymer $(*)$, which is fragmented. Observe Angiogenesis (A). H.E. 200x.

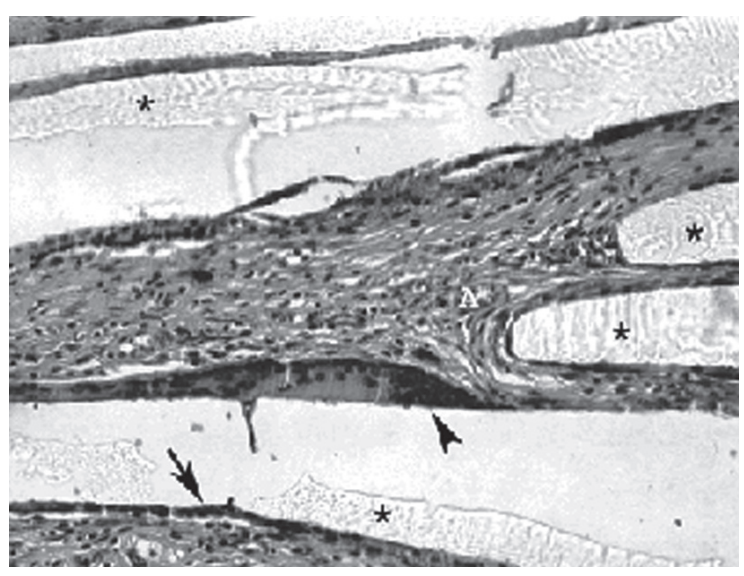

Figure 9. Photomicrography of PLDLA membrane sixty days after implantation. Observe the foreign body giant cell (arrow head), polymer $(*)$ and angiogenesis areas (A). Observe the conjunctive capsule with cells in macrophage-like epitheloid arrangement (arrow head). H.E. 200x.

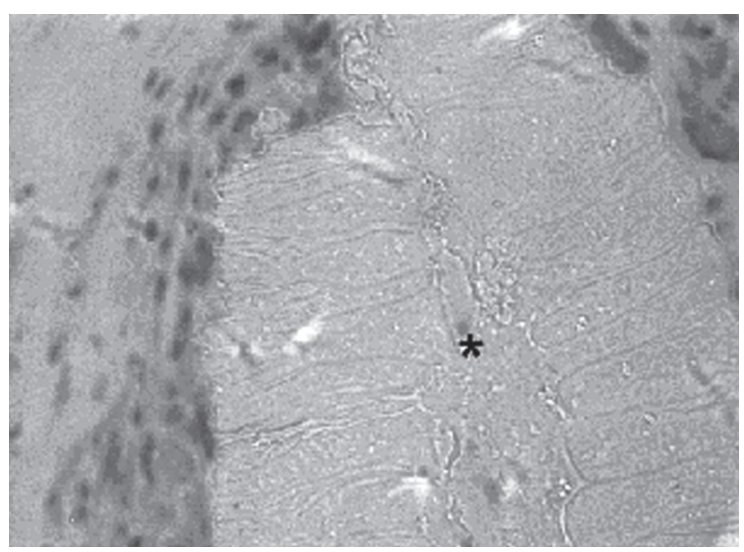

Figure 10.. Photomicrography of the PLDLA membrane under polarized light microscope sixty days after implantation. Observe PLDLA membrane (*). Toluidine Blue 400x. initial formation of the capsule, but when cicatrization is established there is a reduction in type III collagen fibers and an increase in type I collagen fibers. According to Marucci $^{21}$, matrix metalloproteinases have an important role in providing the histoarchitecture required to promote the establishment of type I collagen fibers to the detriment of type III fibers. The production of reticular fibers leads to the formation of a thin, flexible matrix that promotes the movement of cells such as fibroblasts, neutrophils, lymphocytes and macrophages. This matrix becomes dense and thick as cicatrization progresses and there is an increase in the deposition of type I fibers ${ }^{5,22,23}$.

According to Broughton ${ }^{24}$, the cellular proliferation phase is characterized by a massive presence of fibroblasts and endothelial cells; the former are related to the consolidation of the conjunctive capsule, while the latter participate in neoangiogenesis. This neovascularization depends on vascular endothelial growth factor (VEGF). This factor, which is produced by macrophages, platelets, fibroblasts and endothelial cells, attracts venular endothelial cells to form new capillaries that allow tissue regeneration ${ }^{5,25}$. According to Padera and Colton ${ }^{26}$, a low oxygen tension in the pores of polymeric membranes stimulates macrophages to secrete angiogenesis factors that influence endothelial cells.

From the $15^{\text {th }}$ day of implantation onwards, macrophage-like epithelioid cells derived from macrophages were organized around the implant to isolate the polymer fragments and facilitate phagocytosis. Foreign body giant cells were also seen 15 days after implantation ${ }^{27}$. This cellular accumulation occurs when the size of foreign particles exceeds $10 \mu \mathrm{m}^{28}$.

Foreign body giant cells correspond to the final stage of macrophage development. The key biochemical process in the formation of foreign body giant cells involves the mediators interleukin 4 (IL-4) and interferon $\gamma$ (IFN- $\gamma$ ). In the presence of IL-4 and IL-13, macrophages to give rise to identical giant cells that in vivo are very similar to foreign body giant cells. In this context, IL-4 inhibits inflammatory cytokines such as IL-1, tumor necrosis factor- $\alpha$ (TNF $\alpha)$ and IL-8. This fact suggests that the development of foreign body giant cells is related to a decrease in the inflammatory

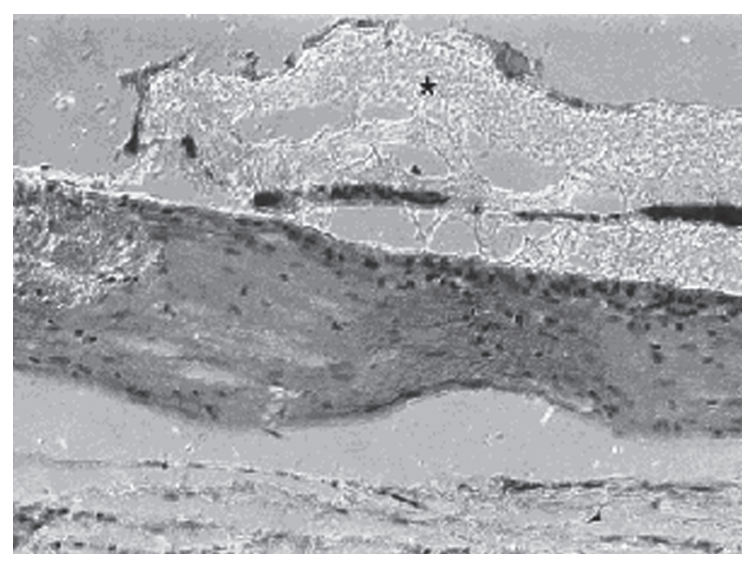

Figure 11. Photomicrography of PLDLA membrane under polarized light microscope ninety days after implantation. Observe the polymer $(*)$. H.E. $200 \times$. 


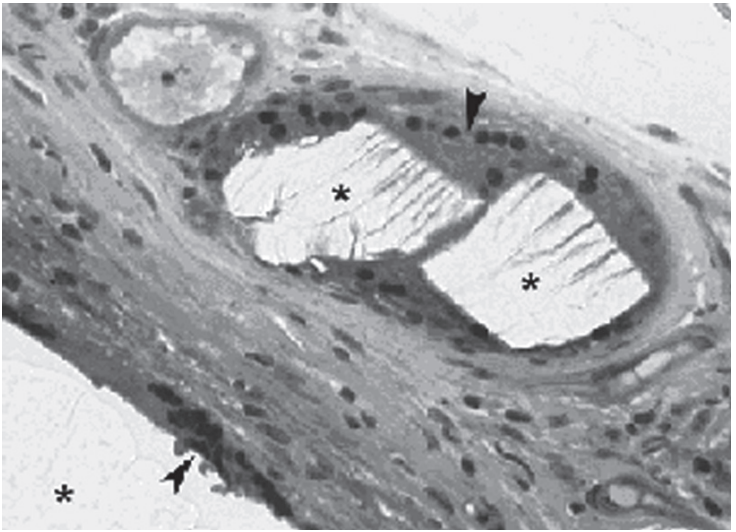

Figure 12. Photomicrography of the PLDLA membrane under polarized light microscope ninety days after implantation. Notice the polymeric fragmentation $\left(^{*}\right)$ and the foreign body giant cells (arrow head) involving the polymer. Toluidine Blue 400x.

response ${ }^{28-31}$. Foreign body giant multinuclear cells are small phagocytes that possess a large number of lysosomes and high respiratory enzymatic activity. Despite the decrease in phagocytic capacity after macrophage fusion, the capacity for degradation of the extracellular matrix is enhanced, which allows for the degradation of collagen ${ }^{28}$.

From the $30^{\text {th }}$ day of implantation onwards there was significant polymer fragmentation. Skeletal muscle movements made the polymeric membrane brittle and the allowed cellular invasion and phagocytosis. Polymeric fragmentation becomes expressive when polymer-tissue connections are involved ${ }^{1}$. Such fragmentation is essential for the performance of myofibroblasts, which are fibroblasts with contractile features similar to those of smooth muscle cells, and allows the contraction of the injured tissues and the promotion of polymer-tissue adhesion during cicatrization $^{5,32}$

During processing of the implants for histological analysis we found there was chemical interference with the natural process of polymer degradation. To examine this phenomenon, we processed the 60 - and 90 - day samples using the conventional xylol/paraffin method that had been used since the beginning of the project and also embedded samples in historesin that does not include xylol as a reagent.

Comparison of the samples obtained by these two methods showed that the only difference between them was the way in which the polymeric membrane underwent degradation. The degradation seen in paraffin-embedded

\section{References}

1. Duek EAR, Barbanti SH and Zavaglia CAC. Polímeros bioreabsorvíveis na engenharia de tecidos. Polímeros. 2005; 15(1):13-21. http://dx.doi.org/10.1590/ S0104-14282005000100006

2. Rezende CA, Luchesi C, Barbo MLP and Duek EAR. Membranas de poli (ácido lático-co-ácido glicólico) como curativos para pele: degradação in vitro e in vivo. Polímeros, 2005; 15(3):232-238. http://dx.doi.org/10.1590/ S0104-14282005000300015 samples was heterogeneous and involved the formation of a 'lace-like' network. In contrast, the degradation seen in historesin-embedded section was slower, more homogeneous and had the appearance of "centripetal cracks in the form of glove fingers". Moreover, in historesin-embedded samples the polymer-tissue connection was more consolidated when compared to paraffin-embedded tissues.

\section{Conclusion}

Based on the results of this study, we conclude that:

- PLDLA implants stimulated the gradual invasion of cells into the implanted implant area and culminated in cell proliferation and the formation of a conjunctive capsule involving the polymer;

- Angiogenesis was essential for the movement of mononuclear cells (macrophages) involved in bioresorption of the polymeric membrane;

- Foreign body cells developed from macrophage-like epithelioid cells. Fifteen days after implantation, foreign body giant cells were always present, which guaranteed degradation of the polymer;

- Polymer fragmentation involved hydrolysis and the movement of skeletal muscle that facilitated PLDLA membrane phagocytosis;

- Xylol interfered with the degradation of PLDLA membranes, as shown by the finding that the "lace-like" degradation pattern became "centripetal cracks in the form of glove fingers" when samples were embedded in historesin; and

- The biocompatibility of PLDLA membranes in vivo, together with the low molecular weight of this polymer, allows this compound to be combined with drugs for distribution to target tissues.

Together, these findings emphasize the biocompatibility and mechanical stability of PLDLA membranes; these properties make this polymer a good alternative for use in a variety of areas.

\section{Acknowledgements}

The authors thank. Débora Regina Machado Silva, Carolina Lucchesi, Grazielle dos Santos Baraúna and Kátia Fernanda Silva (Laboratory of Biomaterials, PUC-SP) for help during this work and Elizabeth Almeida (Laboratory of Histology, PUC-SP) for technical assistance. This work was supported by grants from PIBIC/CEPE (Programa Institucional de Bolsas de Iniciação Científica - Conselho de Ensino Pesquisa e Extensão).

3. Lehle K, Lohn S, Reinerth G, Schubert T, Preuner JG and Birnbeum DE. Cytological evaluation of the tissue-implant reaction associated with subcutaneous implantation of polymers coated with titanium carboxonitride in vivo. Biomaterials. 2003; 25(1):5457-5466.

4. Huang MH, Li S and Hutmacher DW. Degradation and cell culture studies on block copolymers prepared by ring opening polymerization of $\varepsilon$-caprolactone in the presence of poly(ethylene glycol). Journal of Biomedical Materials Research. 2004; 69(3):417-427. PMid:15127388. http://dx.doi. org/10.1002/jbm.a.30008 
5. Silva DRM. Membranas de poli-L (ácido lático): suporte para fibrocondrócitos isolados de menisco e comportamento in vivo no tecido subcutâneo. [Tese]. Campinas: Universidade Estadual de Campinas; 2007.

6. MottaAC and DuekEAR. Síntese e caracterização do copolimero poli (L-co-D,L-ácido láctico). Polímeros. 2007; 17(2):123-129. http://dx.doi.org/10.1590/S0104-14282007000200011

7. Jiang S, He C, Na L, Chen X and Jiang B. Crystallization and ring-banded spherulite morphology of poly(ethylene oxide)-block-poly( $\varepsilon$-caprolactone) diblock copolymer. Macromolecular Chemistry and Physics. 2004; 205:2229-2234. http://dx.doi.org/10.1002/macp.200400204

8. Luciano RM, Zavaglia CAC, Duek EAR and Alberto-Rincon MC. Synthesis and characterization of poly (L-lactic acid) membranes: studies in vivo and in vitro. Journal of Materials Science: Materials in Medicine. 2003; 14:87-94. PMid:15348543. http://dx.doi.org/10.1023/A:1021509722296

9. Middeleton JC and Tipton AJ. Synthetic biodegradable polymers as orthopedic devices. Biomaterials. 2000; 20:2335-2346. http://dx.doi.org/10.1016/S0142-9612(00)00101-0

10. Baraúna G. Regeneração nervosa periférica. [Dissertação] Campinas: Universidade Estadual de Campinas; 2007.

11. Motta AC and Duek EAR. Sinteses, caracterização e degradação "in vitro" do poli (L-ácido lático). Polimeros. 2006; 16:26-32. http://dx.doi.org/10.1590/S0104-14282006000100008

12. Li S, Garreu H and Vert M. Structure relationships in the case of the degradation of massive poly( $\alpha$-hydroxy acids) in aqueous media. Part 1: poly (D,L-lactic acid). Journal of Materials Science: Materials in Medicine. 1990; 1:123-30. http://dx.doi. org/10.1007/BF00700871

13. Duek EAR, Zavaglia CAC and Belangero W. In vitro study of poly(lactic acid) pin degradation. Polymer. 1999; 40:6465-6473. http://dx.doi.org/10.1016/S0032-3861(98)00846-5

14. Suming L, Garreau H and Vert M. Stucture-property relationships in the case of the degradation of massive poly $(\alpha$-hydroxy acids) in aqueous media. Part 3. Influence of the morphology of poly (L-lactic acid). Journal of Materials Science: Materials in Medicine. 1990; 1(4):198-206. http:// dx.doi.org/10.1007/BF00701077

15. Pezzin APT. Obtenção e caracterização de blendas de poli(p-dioxanona)/poli(L-ácido lático) (PPD/PLLA) para aplicação como prótese de menisco biorreabsorvível. [Tese] Campinas: Universidade Estadual de Campinas; 2001.

16. Alberto-Rincon MC, Luciano RM and Duek EAR. The effect of triethylcitrate on the porosity and biocompatibility of poly (Lactic acid) membranes. Brazilian journal of morphological sciences. 2001; 18(1):7-13.

17. Barbanti SH, Zavaglia CAC and Duek EAR. Porous and dense poly (L-lactic acid) membranes: in vitro degradation. Acta Microscopica. 2002; 11(1):85-89.

18. Gorna K and Gogolewski S. Biodegradable porous polyurethane scaffolds for tissue repair and regeneration. Journal of Biomedical Materials Research Part A. 2006; 79A(1):128-138. PMid:16779769. http://dx.doi.org/10.1002/jbm.a.30708

19. Ma Z, Gao C, Gong Y and Shen J. Chondrocyte behaviors on poly-L-lactic acid (PLLA) membranes containing hydroxyl, amide or carboxyl groups. Biomaterials. 2003; 24(1):3725-3730. http://dx.doi.org/10.1016/S0142-9612(03)00247-3
20. Pierce G, Mustoe T, Altrock B, Deuel TF and Thomason A. Role of platelet-derived growth factor in wound healing. Journal of Cellular Biochemistry. 1991; 45(1):319-326. http:// dx.doi.org/10.1002/jcb.240450403

21. Marucci DD, Yu Y, Tavisch J and Bonar S. Matrix metalloproteinases and their inhibitors in bone remodelling following distraction osteogenesis of the sheep mandible. Journal of Cranio-Maxillofacial Surgery. 2002; 30(4):208-212. PMid:12231200. http://dx.doi.org/10.1054/jcms.2002.0289

22. Jagur-Grodzinski J. Polymers for tissue engineering, medical devices, and regenerative medicine. Concise general review of recent studies. Polymers for Advanced Technologies. 2006; 17(1):395-418. http://dx.doi.org/10.1002/ pat.729

23. Shannon C, Thull R and von Recum A. Types I and III collagen in the tissue capsules of titanium and stainless-steel implants. Journal of Biomedical Materials Research. 1997; 34(1):401-408. http://dx.doi.org/10.1002/ (SICI)1097-4636(19970305)34:3<401::AID-JBM15>3.0.C $\mathrm{O} ; 2-\mathrm{I}$

24. Broughton G, Janis $\mathrm{J}$ and Attinger C. The basic science of wound healing. Plastic and Reconstructive Surgery. 2006; 117(1):12-34. PMid:16799372. http://dx.doi. org/10.1097/01.prs.0000225430.42531.c2

25. Silva DRM. Degradação in vivo de membranas de poli (L-ácido lático) contendo plastificante tri-etil-citrato. [Dissertation] Campinas: Institute of Biology, State University of Campinas (UNICAMP); 2002.

26. Padera RF and Colton CK. Time course of membrane microarchitecture-driven neovascularization. Biomaterials. 1996; 17(3):277-284. http://dx.doi. org/10.1016/0142-9612(96)85565-7

27. Zhao Q, Topham NS, Anderson JM, Hiltner A, Lodoen G and Payet R. Foreign body giant cells and polyurethane biostability: in vivo correlation of cell adhesion and surface cracking. Journal of Biomedical Materials Research, 1991; 25(1):177-183. PMid:2055915. http://dx.doi.org/10.1002/jbm.820250205

28. Xia Z and Triffitt JT. A review on macrophage responses to biomaterials. Biomedical Materials. 2006; 1(1):1-9. PMid:18458376. http://dx.doi.org/10.1088/1748-6041/1/1/R01

29. DeFife KM, Jenney CR, McNally AK, Colton E and Anderson JM. Interleukin-13 induces monocyte/macrophage fusion and macrophage mannose receptor expression. The Journal of Immunology. 1997; 158(1):3385-3390. PMid:9120298.

30. Kao WJ, McNally AK, Hiltner A and Anderson JM. Role for interleukin-4 in foreign body giant cell formation on a poly (etherurethane urea) in vivo. Journal of Biomedical Materials Research. 1995; 29(1):1267-1275. PMid:8557729. http:// dx.doi.org/10.1002/jbm.820291014

31. Lam KH, Schakenraad JM, Esselbrugge H, Feijen J and Nieuwenhuis P. The effect of phagocytosis of poly (L-lactic acid) fragment on cellular morphology and viability. Journal of Biomedical Materials Research. 1993; 27(1):1569-1577. PMid:8113245. http://dx.doi.org/10.1002/jbm.820271214

32. Khouw IMSL, van Wachem PB and Plantinga JA.TGF- $\beta$ and bFGF affect the differentiation of proliferating porcine fibroblasts into myofibroblasts in vitro. Biomaterials. 1999; 20(1):1815-1822. http://dx.doi.org/10.1016/S0142-9612(99)00077-0 